\author{
П.Ю. Костенко ${ }^{1}$ В.В. Слободянюк ${ }^{1}$, Д.В. Карлов ${ }^{1}$, С.В. Ветлугін ${ }^{2}$, В.О. Лєбєдєв ${ }^{1}$ \\ ${ }^{1}$ Харківський національний університет Повітряних Сил ім. І. Кожедуба, Харків \\ ${ }^{2}$ Радіоастрономічний інститут Національної академії наук України, Харків
}

\title{
МЕТОД ФІЛЬТРАЦІЇ МУЛЬТИПЛІКАТИВНОГО ШУМУ НА ЗОБРАЖЕННЯХ З ВИКОРИСТАННЯМ ТЕХНОЛОГІЇ СУРОГАТНИХ ДАНИХ
}

У статті розглядається метод фільтрації мультиплікативного шуму на ичирровому зображенні, заснований на представленні гомоморфного образу зображення в векторно-матричному фазовому просторі $i$ використанні нетрадиційних методів багатомірного статистичного аналізу, а саме - технологї сурогатних даних, яка дозволяє з єдиного зображення, спотвореного мультиплікативним шумом, формувати псевдоансамбль “сурогатних” зображень із подальшим їхнім усередненням. Проведено імітаційне моделювання запропонованого методу фільтрації шуму. Проведений візуальний порівняльний аналіз просторової $і$ радіометричної роздільної здатності запропонованого й деяких відомих методів фільтрації шуму та їх чисельних мір якості. Показано, щьо запропонований метод демонструє кращу просторову та радіометричну роздільну здатність у порівнянні з найпоширенішими методами фільтрації шуму.

Ключові слова: цифрове зображення, технологія сурогатних даних, мультиплікативний шум, просторова роздільна здатність, радіометрична роздільна здатність.

\section{Вступ}

Постановка проблеми. Жодна система реєстрації не забезпечує ідеальної якості зображень досліджуваних об'єктів. Зображення, в процесі формування їх системами (фотографічними, голографічними, телевізійними, радіолокаційними), звичайно зазнають впливу різних випадкових завад та/або шумів.

Причинами виникнення шуму на зображенні можуть бути збої в роботі каналу зв'язку, шуми радіо і оптико-електронних систем, що реєструють зображення, дефект плівки або скануючого пристрою й т.д. При формуванні цифрових зображень джерелом шуму можуть бути CCD (charge-coupled device)-детектор (спектрометр) і теплові процеси в елементах фотосенсорів.

Фундаментальною проблемою в галузі обробки зображень $\epsilon$ ефективне видалення шуму при збереженні важливих для наступного розпізнавання та інтерпретації деталей зображення. Складність вирішення даного завдання суттєво залежить від характеру шумів.

На відміну від детермінованих спотворень, які описуються функціональними перетвореннями вихідного зображення, для опису випадкових впливів використовують моделі адитивного та мультиплікативного шумів. В якості статистичної моделі адитивних спотворень при обробці сигналів та зображень звичайно вибирається їх представлення неперервними та імпульсними випадковими впливами [1-3].

Мультиплікативні шуми, впливаючи на зображення, спотворюють і одночасно збільшують просторові зміни інтенсивності зображення [4] (динаміч- ний діапазон їх яскравості). Це у свою чергу створює проблеми фільтрації зображень.

Аналіз останніх досліджень і публікацій. Головна мета будь-якого методу попередньої обробки зображень, спотворених шумом, - це зменшити його рівень i, одночасно із цим, зберегти його деталі та ознаки. Це завдання у випадку спотворень цифрового зображення адитивним шумом може вирішуватися з використанням двох відомих підходів. При реалізації першого підходу виконується обробка пікселів зображення з малої околиці пікселя, що підлягає корекції (локальна обробка). Наприклад, згладжування по Гаусу, анізотропна фільтрація, фільтрація Вінера, порогова вейвлет-обробка й ін. Другий підхід заснований на нелокальному ваговому усередненні (NLM - non-local means) пікселів, що належать різним ділянкам зображення, подібним околиці пікселя, у якому придушується (фільтрується) шум [5]. Обидва підходи (перший більшою мірою) приводять одночасно як до зменшення рівня шуму на зображенні, так і до розмивання (згладжування) його деталей, а отже, і до погіршення їх просторового та радіометричного розділення [2-3].

Іншим шляхом вирішується задача фільтрації зображень у випадку мультиплікативних завад. У більшості випадків використовують статистичні моделі мультиплікативного шуму у вигляді негаусівських розподілів, наприклад, розподілу Релея, логнормального, експоненційного та ін. Така модель добре описує дифузний шум в когерентно-оптичних i радіолокаційних системах, які формують зображення [6]. Наприклад, у системах формування зображень, таких як радіолокатор із синтезованою апертурою (РСА) [7], на радіолокаційних зображен- 
нях виникає мультиплікативна завада в у вигляді “спекл-шуму”, яка обумовлена інтерференцією відбитих сигналів у межах одного елемента розділу [89]. Зерниста структура “спекл-шуму” призводить до похибок ідентифікації дрібних деталей на зображеннях та суттєво погіршує їх візуальне сприйняття, а також ефективність автоматичної обробки. При цьому, на практиці “спекл-шум” може бути просторово корельованим.

На даний час розроблено достатньо методів фільтрації завад на зображеннях, які враховують їх мультиплікативний характер. У той же час відомі методи фільтрації мають ряд недоліків, пов’язаних 3 необхідністю мати апріорну інформацію про інтенсивність і просторову кореляцію завад [10-11].

Відомо, що ефективність фільтрації зображень можна покращити за допомогою усереднення ансамблю зображень, даний метод одержав широке поширення в астрофотографії. За допомогою усереднення можливо придушити шуми, не зруйнувавши детальність зображення, оскільки воно по суті збільшує співвідношення сигнал/шум у зображенні. Додатковим виграшем $є$ те, що усереднення може також підвищити глибину кольоровості зображення за межі можливостей одиночного знімка.

Однак на практиці одержати такий ансамбль не завжди представляється можливим. Сьогодні спостерігається тенденція до підвищення ефективності обробки спостережень із використанням нетрадиційних методів статистики, які частково дозволяють вирішувати проблему дефіциту вимірювальної інформації з інтенсивним використанням комп'ютерних засобів (computer-intensive). Ці засоби об'єднані загальним терміном “чисельний ресемплинг” (resampling), вони дозволяють із єдиного знімка (зображення) формувати псевдоансамбль сурогатних зображень. Відомо декілька методів реалізації зазначеного підходу, які відносять до нетрадиційних методів статистики. Наприклад, бутстреп-методи i їх різновиди, а також технологія сурогатних даних, розроблена для аналізу атракторів динамічних систем. Найбільш відомими є метод “складного ножа" (jackknife) і бутстреп (bootstrap). Ці підходи дозволяють формувати так звані “псевдо вибірки” у випадку, коли немає можливості повторно одержати дійсні спостереження (збільшити обсяг вибірки). Бутстреп орієнтований на розв'язок наступного загального завдання [12]. $€$ випадкова вибірка $\mathbf{X} 3$ деякої генеральної сукупності, а також іiі статистика. Потрібно оцінити деяку чисельну міру варіабельності статистики вибірки $\mathbf{X}$, наприклад, середньоквадратичне відхилення (СКВ) або більш складні чисельні міри. При цьому про статистичні властивості генеральної сукупності практично нічого невідомо, а статистика може бути досить складною функцією або навіть функцією, заданою лише алгоритмічно або програмно й не мати аналітичного представлення. Більше того, елементи вибірки $\mathbf{X}$ можуть бути довільної природи, наприклад, скалярами, векторами, матрицями, зображеннями й т.д. Базова ідея бутстрепа проста - розподіл невідомої генеральної сукупності замінюється емпіричним розподілом спостережуваної вибірки, що еквівалентно заміні невідомої генеральної сукупності іншою (“сурогатною”) генеральною сукупністю, утвореною кінцевим числом “копій” (сурогатів) множини елементів вибірки Х. Потім визначаються шукані характеристики варіабельності (наприклад, коваріаційна матриця). У якості основного методу реалізації бутстрепа на практиці використовують алгоритм формування повторних випадкових вибірок з поверненням (англ. resampling with replacement) [12].

У нелінійному аналізі часових рядів ці підходи назвали технологією одержання сурогатних даних (surrogate data technology) [13-15]. Серед процедур формування сурогатних даних можна виділити дві групи: що зберігають статистичні властивості часових рядів (спостережень), та такі, що зберігають властивості їх атракторів.

До першої групи можна віднести процедури: 3 використанням перетворення Фур'є (Fourier transform algorithm), відому також як процедура (алгоритм) з рандомізацією фаз відліків перетворення Фур'є спостережень (random phase (RP) algorithm) та iз припасуванням амплітуди після перетворення Фур'є (amplitude adjusted Fourier transform algorithm) [16].

До другої групи можна віднести процедури 3 випадковим перемішуванням вхідного масиву даних (random shuffle algorithm), наприклад, ATS-алгоритм (attractor trajectory surrogates) [16-17]. Ці процедури зберігають статистичні й динамічні властивості вхідних сигналів, але вимагають більшого числа операцій для одержання сурогатних даних. У роботах [2-3] було запропоновано використати технологію сурогатних даних для фільтрації адитивного шуму на цифровому зображенні. Однак питання фільтрації мультиплікативних завад в цих роботах залишилися без уваги.

Швидкий ріст потужності доступних обчислювальних засобів створює реальні передумови для успішного застосування методів формування псевдоансамблів для вторинної обробки даних, отриманих вимірювальними системами. Універсальність і непараметричний характер цих підходів дозволяють розраховувати на підвищення ефективності фільтрації мультиплікативних шумів на зображеннях, що функціонують в умовах високої апріорної невизначеності щодо статистичних властивостей сигналів $\mathrm{i}$ завад, а також дефіциті вимірювальної інформації.

Мета статті - розробка та дослідження методу фільтрації зображень, спотворених мультиплікатив- 
ним шумом 3 невідомим розподілом імовірності 3 використання технології сурогатних даних.

\section{Виклад основного матеріалу}

Нагадаємо, що з урахуванням шумових факторів модель оброблюваного зображення можна представити в такий спосіб:

$$
I(x, y)=I_{0}(x, y) R(x, y)+N(x, y)+T(x, y),
$$

де $I(x, y)$ - півтонове зображення;

$I(x, y)$ - оригінальне зображення відбиваючого об'єкта;

$R(x, y)$ - мультиплікативний шум;

$N(x, y)$ - адитивний гаусівський шум;

$T(x, y)$ - імпульсний шум;

$x, y-$ просторові координати.

У практиці формування радіо i оптикоелектронних зображень часто вважається, що мультиплікативний шум домінуе над адитивними шумами і ними можна знехтувати. Тому модель зображення, яка буде враховувати тільки мультиплікативний шум, можна представити у вигляді:

$$
I(x, y)=I_{0}(x, y) R(x, y) .
$$

Далі будемо дотримуватись відомого підходу щодо гомоморфної фільтрації мультиплікативного шуму [8]. Під ним розуміють техніку в цифровій обробці сигналів і зображень, за участю нелінійного відображення спотвореного зображення в інший простір, в якому може бути застосована технологія сурогатних даних, і відображено назад у вихідний простір.

Логарифмічний образ спостережуваного 3ображення, визначимо у вигляді суми двох доданків:

$$
\ln I(x, y)=\ln I_{0}(x, y)+\ln R(x, y) .
$$

До значень $\ln I(x, y)$ застосовується векторна реалізація методу SDT (Surrogate Data Technology) фільтрації, що зменшує вплив адитивної компоненти $\ln R(x, y)$, пов'язаної з мультиплікативним шуMOM.

Нижче розглянемо особливості використання технології сурогатних даних для попередньої обробки цифрових зображень, спотворених мультиплікативним шумом, з використанням ATS-алгоритму.

\section{Метод фільтрації шуму з використанням ATS-алгоритму формування сурогатних даних}

В роботі [18] запропоновано застосування технології сурогатних даних у некогерентному спектральному аналізі одновимірних сигналів при низьких відношеннях сигнал/шум. При цьому за спостереженням сигналу формувався ансамбль “сурогатних" спостережень, і для кожного елемента ансамб- лю формувалась оцінка коваріаційої матриці. У результаті формувався ансамбль сурогатних оцінок коваріаційної матриці. Після їхнього усереднення виходила так звана “сурогатна” матриця, яка надалі використовувалася для спектрального аналізу відомими методами. Слід зазначити, що SDT досить універсальна й може бути застосована не тільки до вирішення задачі фільтрації шуму в одновимірних сигналах.

ATS-алгоритм формування сурогатних даних припускає занурення скалярного (часового) ряду в псевдофазовий простір. Образом часового ряду в цьому просторі буде атрактор, властивості якого залежать від рівня шуму в спостереженні. Вихідними даними для використання ATS-алгоритму $\epsilon$ множина точок атрактора. Цей алгоритм реалізує технологію сурогатних даних і може бути застосований до формування сурогатних зображень після використання відомих методів розгорнення растрових зображень - упорядкування елементів зображення у вектор скалярних значень [2]. До впорядкованих таким чином значень растрового зображення застосовується добре розвинений метод вкладення часових послідовностей в псевдофазовий простір. Властивості атрактора динамічної системи, стан якої описується векторними функціями часу (або часовими рядами), можуть бути досліджені на основі теореми Такенса і методу Гроссберга-Прокачиа [3], запропонованих для оцінки кореляційної розмірності скалярного часового ряду, зануреного в псевдофазовий простір. По суті, фільтрація шуму на зображенні у матричному представленні зводиться до обробки їх рядків і стовпців з використанням технології сурогатних даних, заданих вектором зі скалярними компонентами.

Будемо вважати, що модель цифрового гомоморфного образу зображення представляється квадратною матрицею $\mathbf{X}$. Кожний рядок (стовпець), який має $N$ пікселів, занурюється (вкладається) в псевдофазовий простір розмірності $d$. Тоді для кожного рядка (стовпця) матриці $\mathbf{X}$ ATS-алгоритм формування сурогатних даних буде складатися 3 наступних кроків:

1) виділяємо $k$-й рядок растрового зображення (матриці $\mathbf{X}$ ), який можна записати у вигляді $\mathbf{x}_{k}=\left(x_{1, k}, x_{2, k}, \cdots, x_{N, k}\right)$, і виконуємо його вкладення в псевдофазовий простір розмірності $d$, елементами якого будуть точки, задані векторами:

$$
\begin{aligned}
& \mathbf{y}_{1, k}=\left(x_{1, k}, x_{2, k}, \cdots, x_{d, k}\right), \\
& \mathbf{y}_{2, k}=\left(x_{2, k}, x_{3, k}, \cdots, x_{d+1, k}\right), \\
& \mathbf{y}_{n, k}=\left(x_{n, k}, x_{n+1, k}, \cdots, x_{n+d, k}\right) .
\end{aligned}
$$


2) вибираємо початкове значення $\mathbf{s}_{1, k} \in\left\{\mathbf{y}_{n, k} \mid n=1, \cdots, N-d\right\}$.

3) встановлюємо значення параметра циклу $i=0$.

4) випадковим чином вибираємо точку $\mathbf{s}_{1, k} 3$ безлічі $\left\{\mathbf{y}_{n, k}\right\}_{n=1}^{N-d}$, яка попадає в околицю (гіперсферу) радіуса $\boldsymbol{\varepsilon}_{j, k}$ точки, наприклад, точки $\mathbf{y}_{j, k}$.

5) встановлюємо $\mathbf{s}_{i+1, k}=\mathbf{y}_{j+1, k}$ та збільшуємо $i$ на одиницю.

6) повторюємо кроки 4 та 5 доти, поки не виконається умова $i=N-d$.

повертаємо значення $m$-го компонента $(m \leq d), \quad$ кожного 3 векторів $\left\{\left(\mathbf{s}_{n, k}\right)_{m}: n=1,2, \cdots, N-d\right\}$, які представляють елементи однієї сурогатної реалізації рядка (стовпця) зображення $\mathbf{s}_{\text {sur }, k}=\left\{\mathbf{s}_{\text {sur },(i, k)}\right\}_{i=1}^{N-d}$.

3 метою фільтрації шуму на зображенні сформуємо ансамбль сурогатних реалізацій $\left\{\mathbf{s}_{s u r,(q, k)}\right\}_{q=1}^{N_{s}}$ (повторюючи $N_{s}$ раз ATS-алгоритм для кожного рядка та стовпця зображення) і визначимо його математичне сподівання

$$
<\mathbf{s}_{s u r, k}>=\frac{1}{N_{s}} \sum_{q=1}^{N_{s}} \mathbf{s}_{\text {sur },(q, k)},
$$

де $q$ - номер сурогатної реалізації рядка (стовпця) зображення;

$k$ - номер рядка (стовпця).

Таким чином, формуються матриці $<\mathbf{s}_{s u r}>_{p я д}$, $<\mathbf{s}_{\text {sur }}>_{\text {cтовn }} 3$ оцінками усіх сурогатних рядків та стовпців матриці $\mathbf{X}$, які визначають оцінку матриці гомоморфного образу зображення $\hat{\mathbf{X}}_{\text {SDT }}=\left(<\mathbf{s}_{\text {sur }}>_{\text {pяd }}+<\mathbf{s}_{\text {sur }}>_{\text {cmoвn }}>\right) / 2$.

Для визначення оцінки зображення потрібно потенціювати оцінку матриці $\hat{\mathbf{X}}_{S D T}$ :

$$
\hat{\mathbf{I}}_{\text {sur }}=\exp \hat{\mathbf{X}}_{S D T} .
$$

\section{Результати імітаційного моделювання}

Робота алгоритму реалізує запропонований метод SDT-фільтрації, та визначається наступними параметрами: розмірністю вкладення $d$, кількістю сурогатних реалізацій $N_{s}$ і радіусом покриття $\boldsymbol{\varepsilon}$. Слід зазначити, що радіус побічно залежить і від дисперсії шуму. При реалізації цього методу використовується адаптивна до шуму і розміру вкладення оцінка параметра $\boldsymbol{\varepsilon}$, яка дорівнює середньоквадратичному відхиленню гістограми розподілу відстаней між усіма парами векторів $\left\{\mathbf{y}_{n, k}\right\}_{n=1}^{N-d}$.

В якості прикладу на рис. 1 показано фазові портрети $k$-го рядка оригінального (рис. $1, \mathrm{a})$, спотвореного (рис. 1, б) і сурогатного зображення (рис. 1, в), на рис. 2 відповідні їм реалізації рядків.

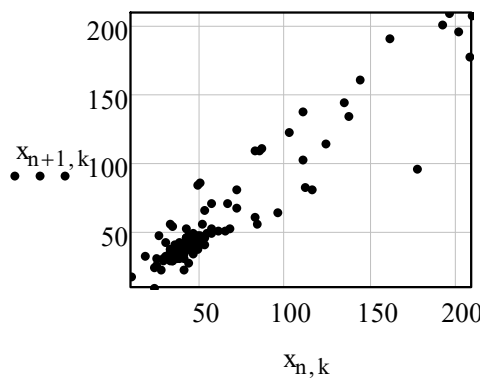

$a$
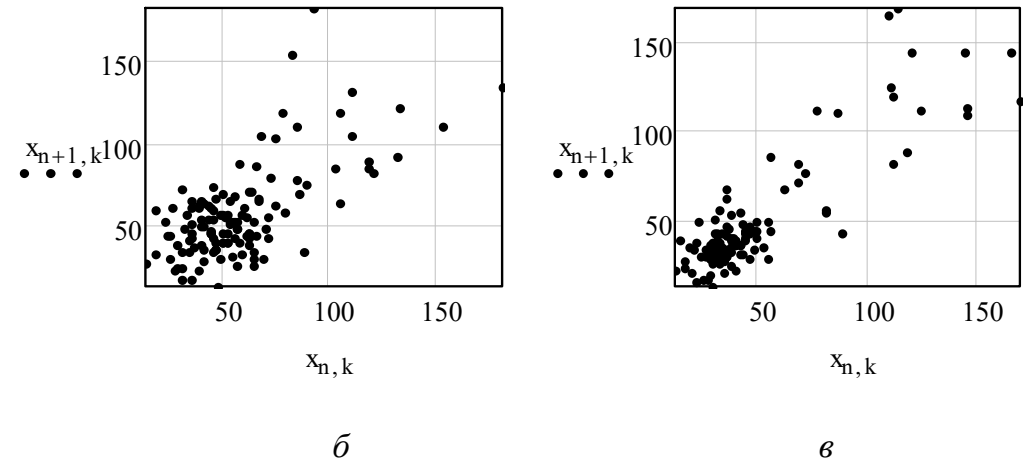

Рис. 1. Фазові портрети $k$-го рядка:

a - оригінального зображення;

б - спотвореного зображення;

в - сурогатного зображення

Джерело: розроблено авторами. 

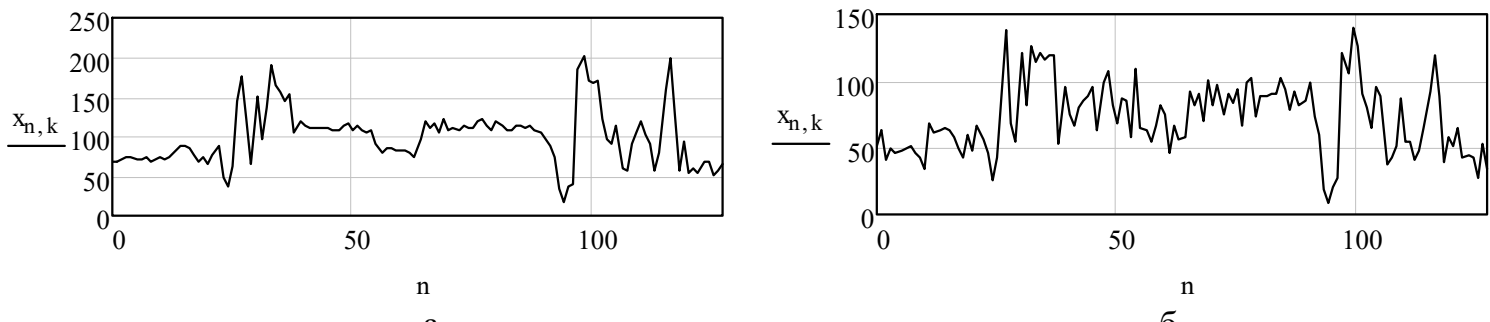

a

6

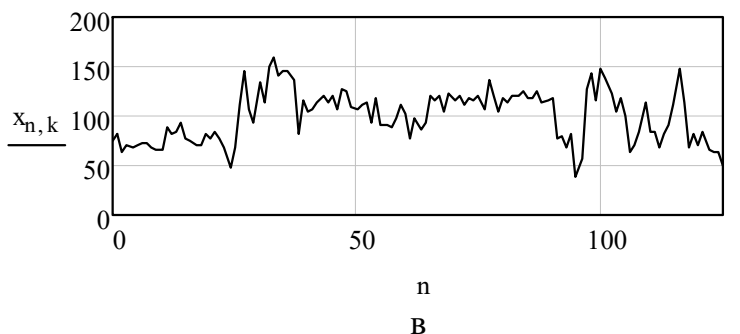

Рис. 2. Реалізація рядка:

a - оригінального; б - спотвореного; в - сурогатного зображення Джерело: розроблено авторами.

Легко помітити, що усереднення сурогатних реалізацій кожного рядка спотвореного мультиплікативним шумом зображення дозволяє усунути розмиття його фазового портрета, i, як наслідок, приводить до фільтрації шуму.

На рис. 3 показані результати моделювання запропонованого методу SDT-фільтрації на оригінальному зображенні (рис. 3, а), спотвореному мультиплікативним шумом (рис. 3,6$) 3$ логнормальним розподілом $\operatorname{LN}\left(\sigma^{2}, \mu\right)$ для параметрів $\mu=0$ та $\sigma=1$, які обумовлюють наступне значення дисперсії шуму $\left(e^{\sigma^{2}}-1\right) e^{2 \mu+\sigma^{2}}=4,671$. Результат фільтрації спотвореного шумом тестового зображення наведений на рис. 3 , в. Його візуальний аналіз показує, що векторна реалізація метода SDT-фільтрації дозволяе придушувати мультиплікативний шум.

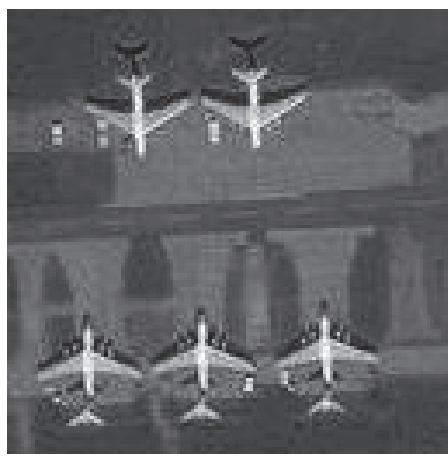

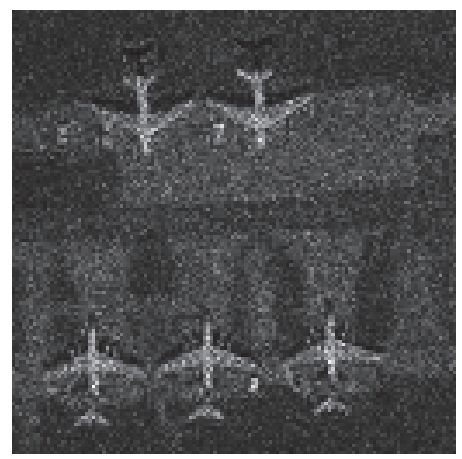

б

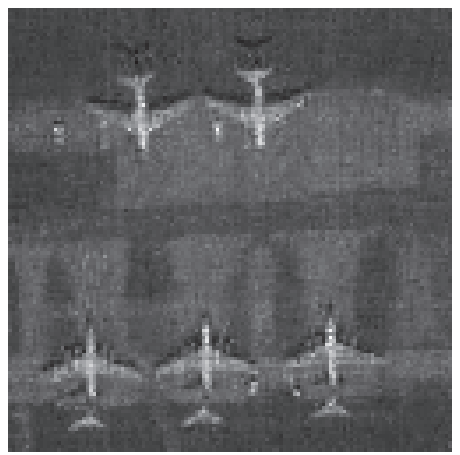

B

Рис. 3. Результати моделювання методу SDT-фільтрації a - оригінальне зображення; б - зображення спотворене мультиплікативним шумом; в - результат SDT-фільтрації

Джерело: розроблено авторами розроблено авторами за даними [2].

До недоліків векторної реалізації методу SDTфільтрації слід віднести можливу появу артефактів на зображенні (хибні лінії у вигляді сітки), що погіршують його візуальну якість. Такі артефакти 3'являються в наслідок роздільної обробки рядків і стовпців, яка не враховує інформацію про просторову залежність між пікселями зображення в їх околиці.
Коротко викладемо метод SDT-фільтрації шуму на зображенні адаптований до матричних даних, заснований на використанні кластерів (фрагментів зображень) $\left\{\mathbf{A}_{i}\right\}$, що дозволяє враховувати просторову залежність між пікселями. Для цього виконана модифікація SDT-методу фільтрації, викладеного вище, яка полягає у тому, що елементами в псевдо- 
фазовому просторі розмірності $d$ будуть точки, які відповідають

векторам

$\left\{\mathbf{y}_{i}=\left(\mathbf{A}_{i}, \ldots, \mathbf{A}_{(i+d-1)}\right)\right\}_{i=1}^{(N-m+1)^{2}-d+1}$,

елементами

яких $є$ фрагменти зображень $\left\{\mathbf{A}_{i}\right\}$ розміром $(m \times m)$.

\section{Порівняльний аналіз методу SDT-фільтрації 3 деякими відомими методами}

Проведемо порівняльний аналіз запропонованого методу SDT-фільтрації з методом локальної фільтрації Вінера та методом NLM-фільтрації, що поєднує групу методів нелокальної фільтрації, у яких значення оцінюваного пікселя знаходиться ваговим підсумовування пікселів, що перебувають у різних фрагментах цифрового зображення, щодо околиці оцінюваного пікселя. Його також можна віднести до групи методів нелокального усереднення і різних його модифікацій. Для зручності подальшого порівняння їх якості коротко опишемо кожний 3 них.

Фільтр Вінера є оптимальним за критерієм мінімуму середньоквадратичної похибки між вихідним (оригінальним) и і відфільтрованим зображенням $\hat{\mathbf{u}}$ [19]. Якщо припустити, що безліч пікселів $u(i, j)$ оригінального зображення також $є$ білим гаусівським шумом, то для фільтра Вінера будемо мати дуже просту скалярну форму:

$$
\begin{aligned}
& \hat{u}(i, j)=\frac{\sigma_{u}^{2}(i, j)}{\sigma_{u}^{2}(i, j)+\sigma_{\xi}^{2}(i, j)} \times \\
& \times\left[g(i, j)-\mu_{u}(i, j)\right]+\mu_{u}(i, j),
\end{aligned}
$$

де $\mu_{u}$ й $\sigma_{u}^{2}$ - середнє значення (можливо рівне нулю) і дисперсія в околиці пікселя $u(i, j)$, яка задається ковзним вікном;

$g(i, j)$ - піксель зображення, яке фільтрується $\mathbf{g} ; \sigma_{\xi}^{2}$ - дисперсія адитивного шуму на зображенні $\mathbf{u}$.

Кожний піксель $\hat{u}(i, j)$ на виході фільтра є сумою локального середнього значення з околиці вхідного пікселя $u(i, j)$ й локального значення контрастності $\left[g(i, j)-\mu_{u}(i, j)\right]$, відмасштабованого так, що в областях з великою деталізацією, де дисперсія шуму $\sigma_{\xi}^{2}$ набагато менше, ніж дисперсія зображення $\sigma_{u}^{2}$, коефіцієнт масштабування дуже близький до одиниці, а вихідний піксель $\hat{u}(i, j)$ дуже близький до вхідного пікселя $u(i, j)$ з невеликою фільтрацією, у той час як в областях з низькою деталізацією, де дисперсія зображення нижче, вихідний піксель більше схожий на локальне середнє значення.

Не формально фільтрація зображення g 3 використанням методу NLM-фільтрації [5; 19] може бути описана послідовністю наступних кроків:

1) для оброблюваного пікселя $g(i, j)$ зображення $\mathbf{g}$ вибираємо квадратну околицю фіксованого розміру із центром у цьому пікселі;

2) визначаємо околиці $L_{l, p}$ того ж зображення, центровані на пікселі $(l, p)$, подібні до околиці $L_{i, j}$ оброблюваного пікселя $g(i, j)$ зображення $\mathbf{g}$ центрованої на піксель $(i, j)$, використовуючи зважену евклідову відстань $\left\|\mathbf{g}\left(L_{i, j}\right)-\mathbf{g}\left(L_{l, p}\right)\right\|_{2, a}^{2}, \quad \mathbf{y}$ якому вагові коефіцієнти визначаються у вигляді гаусівського ядра, що має середньоквадратичне відхилення $a$;

3) визначаємо вагу подібного до $(i, j)$ пікселя $(l, p)$ в підсумковій оцінці пікселя $(i, j)$ :

$$
\begin{aligned}
w(i, j, l, p) & =\frac{1}{Z(i, j)} e^{-\frac{\left\|\mathbf{g}\left(L_{i, j}\right)-\mathbf{g}\left(L_{l+i, p+j}\right)\right\|_{2, a}^{2}}{h^{2}}}, \\
Z(i, j) & =\sum_{l, p} e^{-\frac{\left\|\mathbf{g}\left(L_{i, j}\right)-\mathbf{g}\left(L_{l+i, p+j}\right)\right\|_{2, a}^{2}}{h^{2}}},
\end{aligned}
$$

де $h$ - параметр, що впливає на якість фільтрації цифрового зображення;

4) формуємо підсумкову оцінку пікселя на основі наступного виразу:

$$
\hat{u}(i, j)=\sum_{l, p} w(i, j, l, p) g(i+l, j+p) .
$$

При використанні гаусівської (некомпактної) функції приналежності, яку застосовують у базовому методі NLM-фільтрації при ваговому підсумовуванні елементів зображення виникає проблема, викликана внеском великої кількості елементів зображення 3 малими ваговими коефіцієнтами, які можуть створювати збурювання більш значимих значень зображення, що брали участь в алгоритмі фільтрації з більшими вагами.

Розглянемо на тестовому зображенні методичні похибки фільтрації обраних для порівняння алгоритмів. В цьому випадку будемо вважати, що мультиплікативний шум відсутній. Ці похибки можуть суттєво позначитись на результаті фільтрації навіть при незначних рівнях мультиплікативних завад. Алгоритми фільтрації мали наступні параметри: 
- SDT-фільтр - розмірність вкладення $d=3$, число сурогатних реалізацій $N_{s}=100$, розмір кластерів (фрагментів зображення) $(3 \times 3)$;

- NLM-фільтр - розмір пошукового вікна $(5 \times 5)$, розмір подібних фрагментів у середині вікна “подоби” (3×3), параметр згладжуючого ядра обраний рівним середньоквадратичному відхиленню (СКВ) шуму $h=0,2$ при можливій його наявності;

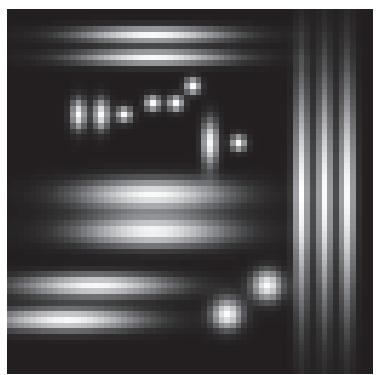

a

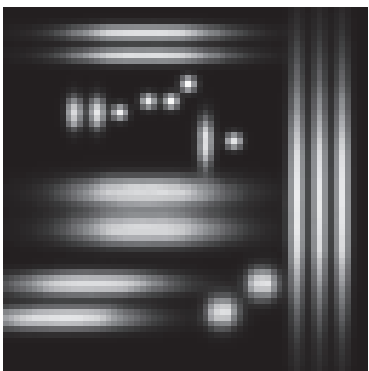

6
- фільтр Вінера - розмір вікна $(3 \times 3)$.

Результати фільтрації обраних для порівняння наведених алгоритмів фільтрації показані на рис. 4, де: а - тестове зображення; б - результат SDTфільтрації; в - результат фільтрації методом NLM; г - результат фільтрації з використанням фільтра Вінера.

Рис. 4. Результати фільтрації обраних для порівняння наведених алгоритмів фільтрації: а -тестове зображення; б - результат SDT-фільтрації; в - результат фільтрації методом NLM; г-результат фільтрації з використанням фільтра Вінера Джерело: розроблено авторами.

Для порівняння обраних методів фільтрації можна проаналізувати дві добре відомі чисельні міри якості фільтрації: PSNR peak signal-to-noise ratio) та SSIM (structure similarity)[2-3; 5; 19], які зведені в табл. 1. Слід зазначити, що ці міри відображають різні властивості методів фільтрації.

Таблиця 1

Чисельні міри якості

\begin{tabular}{|c|c|c|}
\hline Морра якості & PSNR, дБ & SSIM \\
\hline SDT-фільтр & 34,121 & 0,997 \\
\hline NLM-фільтр & 33,32 & 0,996 \\
\hline Фільтр Вінера & 23,287 & 0,957 \\
\hline
\end{tabular}

Джерело: розроблено авторами.

3 аналізу результатів, наведених у табл. 1, випливає, що метод SDT-фільтрації демонструє кращі чисельні показники оцінок PSNR та SSIM. У той же час метод NLM-фільтрації незначно поступається методу SDT-фільтрації за цими показниками якості. Проте недоліком цього методу є суттєва чутливість якості фільтрації до параметру згладжування. Його вибір залежить від статистичних характеристик шуму, які часто апріорі невідомі. Важливо відзначити, що міри якості, наведені в табл. 1, можуть не узгоджуватися 3 найкращим візуальним сприйняттям i кращої просторової й/або радіометричної роздільною здатності. Очевидно, що однієї або декількох розглянутих мір може бути недостатньо, щоб оцінити якість фільтрації зображення.

На рис. 5 наведені контурні графіки відповідних зображень, для яких кількісні значення рівнів не вказані (щоб їх не захаращувати). Контурні графіки дозволяють порівнювати просторову роздільну здатність відповідних алгоритмів фільтрації.
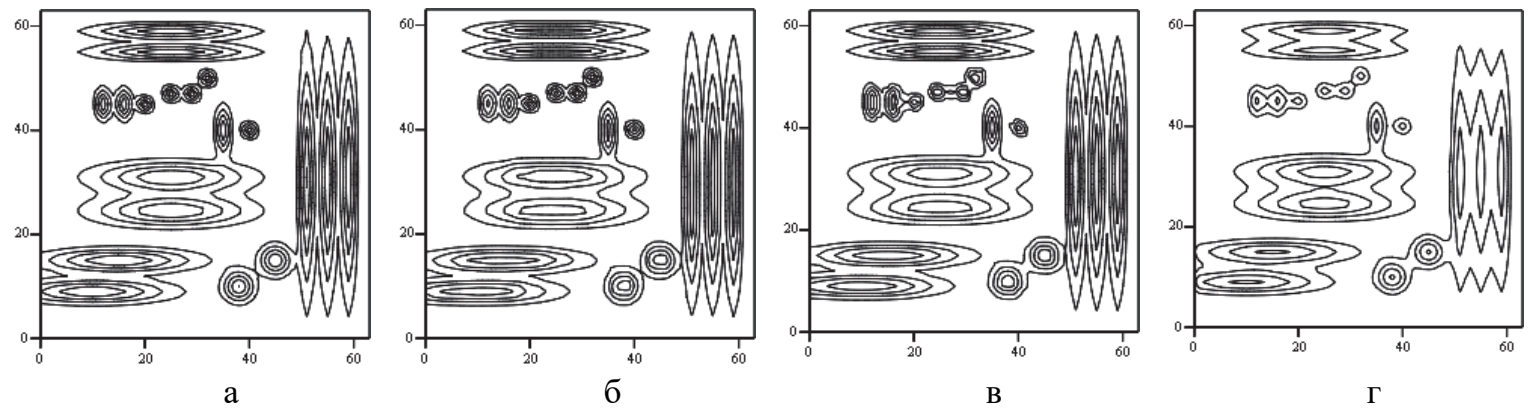

Рис. 5. Контурний графік:

a - тестового зображення; б - результату SDT-фільтрації; в - результату фільтрації методом NLM; г - результату фільтрації з використанням фільтра Вінера

Джерело: розроблено авторами. 


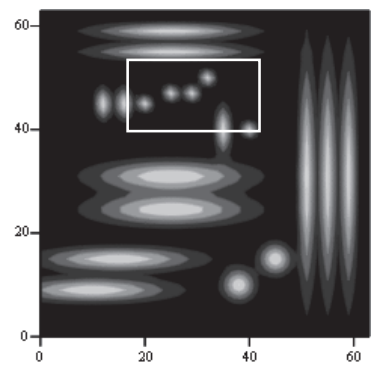

$\mathrm{a}$

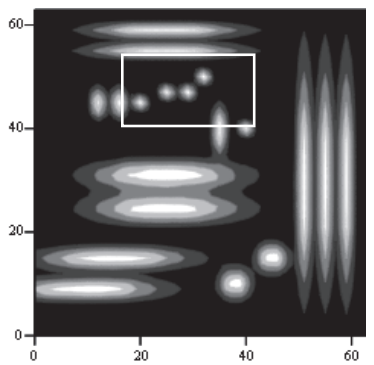

6

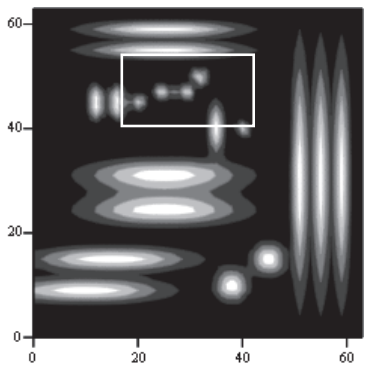

B

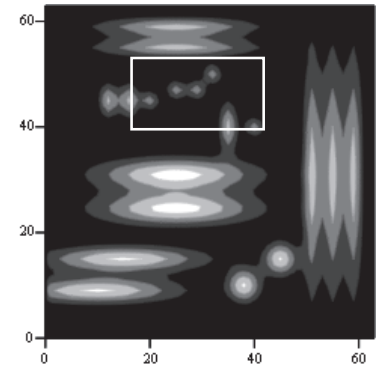

$\Gamma$

Рис. 6. Контури рівної яскравості:

a - тестове зображення; б - результат SDT-фільтрації; в - результат фільтрації методом NLM; г-результат фільтрації з використанням фільтра Вінера

Джерело: розроблено авторами.

На рис. 6 показані контури рівнів яскравості аналізуємих зображень з різними градаціями (щільностями) сірого кольору, а також для наочності фрагменти зображень, що включають його дрібні деталі.

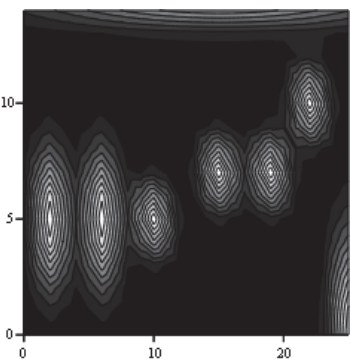

a

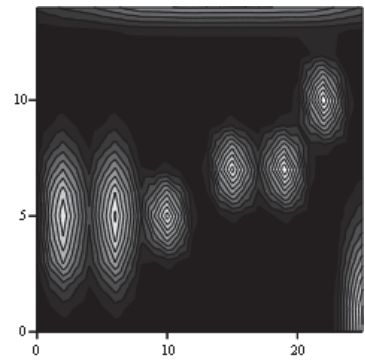

6
Фрагменти зображень у вигляді контурів рівної яскравості, які показані на рис. 7, надають інформацію про радіометричну роздільну здатність досліджуваних алгоритмів.

Рис. 7. Контури рівної яскравості

а - тестове зображення; б - результат SDT-фільтрації; в - результат фільтрації методом NLM; г - результат фільтрації з використанням фільтра Вінера

Джерело: розроблено авторами.

3 візуального аналізу зображень (рис. 4-7) можна зробити висновок, що за методичною похибкою фільтр Вінера помітно поступається SDT-фільтру та NLM-фільтру просторовою та радіометричною роздільною здатністю. В той же час SDT-фільтр має помітно кращу просторову роздільну здатність в порівнянні з NLM-фільтром. При візуальному аналізі радіометричної роздільної здатності цих фільтрів на дрібних деталях зображення (рис. 7) помітно, що вона дещо краща для SDT-фільтра, бо визначається більшою кількістю градацій значень сірого кольору, що відповідають переходу від яскравості абсолютно “чорного" до абсолютно “білого” кольору.

Розглянемо запропонований метод SDTфільтрації на прикладі придушення мультиплікативного шуму на фрагменті вихідного радіолокаційного зображення (рис. 8) з невідомою імовірністю його розподілу, на який впливає на фізичний механізм його утворення.

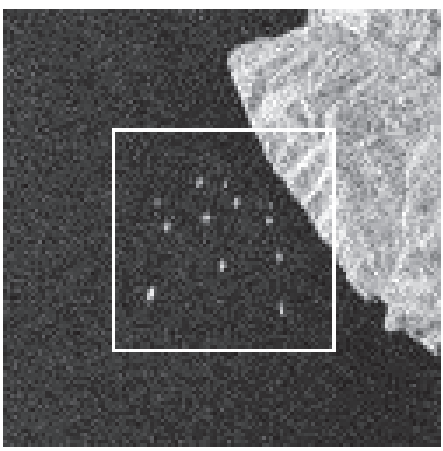

Рис. 8. Радіолокаційне зображення з виділеним на ньому фрагментом, що містить малорозмірні об'єкти

Джерело: [3].

Фрагмент (рис. 9, а) містить багато малорозмірних об'єктів, які повинні бути збережені після придушення шуму. 


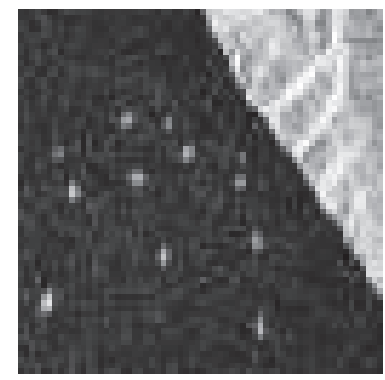

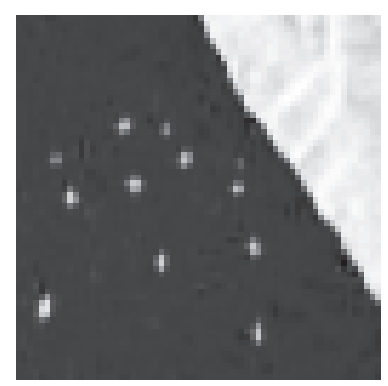

6

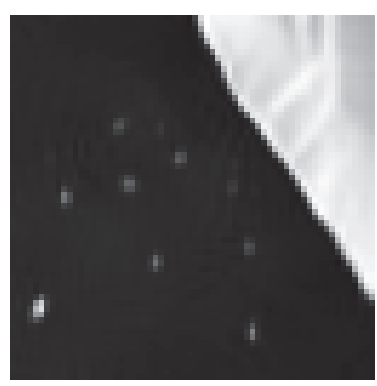

B

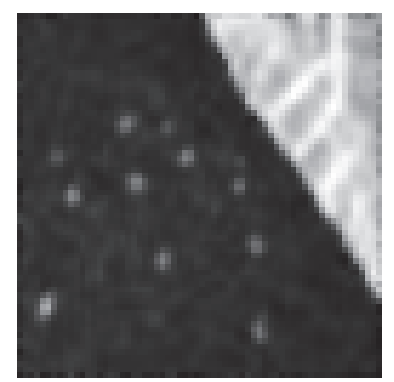

$\Gamma$

Рис. 9. Малорозмірні об’єкти, які повинні бути збережені після придушення шуму a - фрагмент зображення; б - результат SDT-фільтрації; в - результат фільтрації методом NLM; г-результат фільтрації з використанням фільтра Вінера

Джерело: розроблено авторами розроблено авторами за даними [3].

Візуальний аналіз отриманих зображень показує істотне зменшення шуму після SDT-фільтрації та збереження дрібних деталей. У той же час, методи NLM-фільтрації і Вінерівської фільтрації не тільки розмивають дрібні деталі зображення, але й поглинають деякі з них, що вказує на зменшення просторової та радіометричної роздільної здатності цих фільтрів. На зображенні, обробленому з використанням локального фільтра Вінера (рис. 9, а) присутній залишковий шум.

Візуальна оцінка результату фільтрації вихідного зображення відіграє важливу роль для оцінки якості обраного методу придушення шуму. Однак наявність суб'єктивізму при використанні візуальної оцінки методів фільтрації цифрових зображень затрудняє вибір кращого методу фільтрації, тому що на результати суб'єктивних експертних оцінок впливають характер розглянутих зображень і навколишнє оточення. Для поліпшення сприйняття зо-

браження необхідно, щоб його яскравість була, по можливості, розподілена рівномірно по всьому припустимому діапазоні. У цьому випадку цифрове зображення виглядає високо контрастним. На практиці ця умова може не виконуватися у випадку малого динамічного діапазону яскравості зображення. Тому візуальні оцінки якості методу придушення шуму необхідно доповнювати чисельними мірами оцінки залишкового шуму на зображенні і його просторової та радіометричної роздільної здатності важливої при інтерпретації тематичних зображень.

Покажемо, що імовірність розподілу мультиплікативних завад суттєво не впливає на якість придушення шуму методом SDT-фільтрації.

На рис. 10 показані фрагменти: а - зображення спотвореного мультиплікативним шумом 3 розподілом Релея; б - результат SDT-фільтрації; в - результат фільтрації методом NLM; г - результат фільтрації з використанням фільтра Вінера.

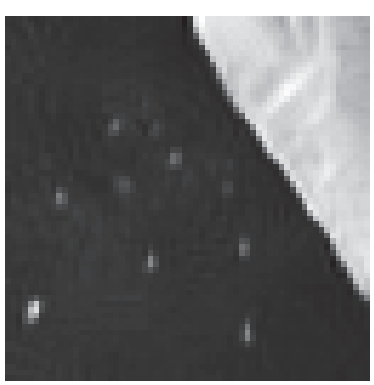

B

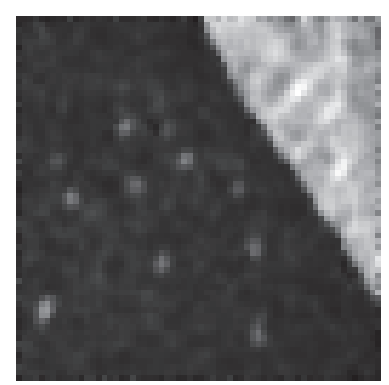

$\Gamma$

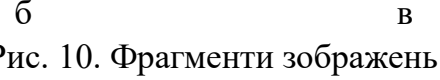

a - фрагмент зображення, спотвореного мультиплікативним шумом з розподілом Релея; б - результат SDTфільтрації; в - результат фільтрації методом NLM; г- результат фільтрації з використанням фільтра Вінера Джерело: розроблено авторами за даними [3].

Легко помітити, що метод SDT-фільтрації зображення, спотвореного мультиплікативним шумом 3 розподілом Релея, має кращу роздільну просторову та радіометричну здатність. Слід зазначити, що при моделюванні алгоритмів фільтрації в якості мультиплікативного використовувались шуми з розподілом Релея з параметром $\sigma=0,27$, якому відповідає дисперсія шуму $D \approx 0,033$.
На рис. 11 показані фрагменти: а - зображення спотвореного мультиплікативним шумом 3 логнормальнім розподілом для параметрів $\mu=0$ та $\sigma=0,18$, які обумовлюють наступне значення дисперсії шуму $D \approx 0,033 ;$ б - результат SDT-фільтрації; в - результат фільтрації методом NLM; г - результат фільтрації з використанням фільтра Вінера. 


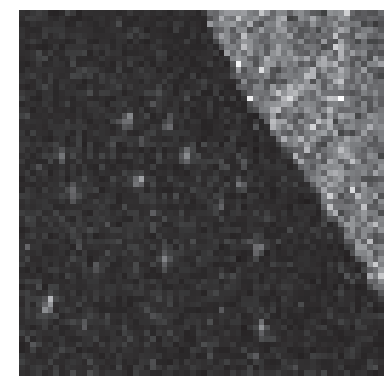

a

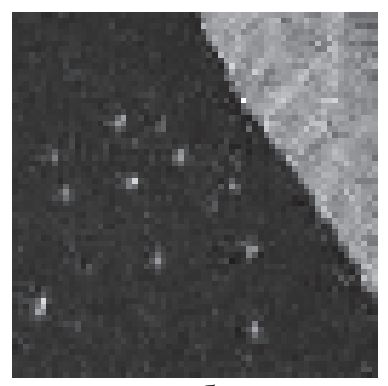

6

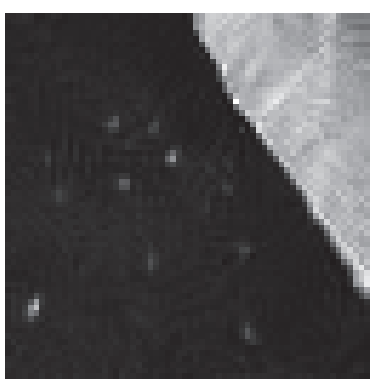

B

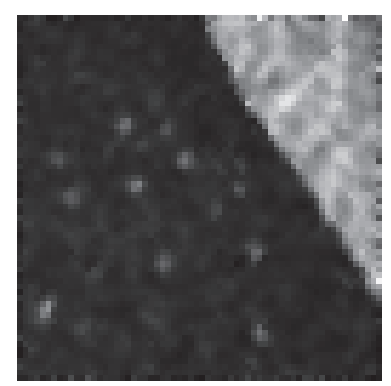

$\Gamma$

Рис. 11. Фрагменти зображень:

a - фрагмент зображення, спотвореного мультиплікативним шумом з логнормальним розподілом;

б - результат SDT-фільтрації; в - результат фільтрації методом NLM;

Г - результат фільтрації з використанням фільтра Вінера

Джерело: розроблено авторами за даними [3].

Легко помітити, що метод SDT-фільтрації зображення, спотвореного мультиплікативним шумом 3 логнормальним розподілом, також має кращу просторову та радіометричну роздільну здатність в порівнянні з методами NLM та Вінерівської фільтрації. $\mathrm{B}$ той же час вид розподілу шуму при однаковій дисперсії суттєво не впливає на якість фільтрації.

\section{Висновки}

У роботі запропонований метод фільтрації зображень, заснований на застосуванні технології сурогатних даних до образа оригінального зображення в узагальненому векторно-матричному фазовому просторі. Його точками є кластери фрагментів зображення. Результати імітаційного моделювання показали, що запропонований метод узагальненої
SDT-фільтрації має кращу просторову та радіометричну роздільну здатність, ніж обрані для порівняння локальний і нелокальний методи фільтрації шуму. У той же час, узагальнений SDT-фільтр має помітно кращі властивості за ступенем фільтрації шуму у метриці PSNR та SSIM в порівнянні з NLMфільтру та фільтру Вінера.

Слід зазначити, що розроблений метод узагальненої SDT-фільтрації мультиплікативного шуму на зображенні, на відміну від базового методу NLMфільтрації, $є$ адаптивним до інтенсивності спотворення зображення, що дозволяє підвищити якість фільтрації на етапі попередньої обробки радіолокаційних та оптико-електронних зображень в умовах дефіциту апріорної інформації про статистичні властивості шуму.

\section{Список літератури}

1. Фалькович С. Е., Костенко П. Ю. Основы статистической теории радиотехнических систем. Харьков : НАУ ХАИ, 2005. $390 \mathrm{c}$.

2. Kostenko P. Y., Slobodyanuk V. V., Plahotenko O. V. Method of image filtering using singular decomposition and the surrogate data technology. Radioelectronics and Communications Systems. 2016. Vol. 59. No. 9. P. $409-416$. https://doi.org/10.20535/S0021347016090041.

3. Kostenko P. Y., Slobodyanuk V. V., Kostenko I. L. Method of image denoising in generalized phase space with improved indicator of spatial resolution. Radioelectronics and Communications Systems. 2019. Vol. 62. No. 7. P. 368-375. https://doi.org/10.20535/S0021347019070045.

4. Білинський Й. Й., Мельничук А. О., Павлюк О. А. Математична модель спекл-шуму та аналіз фільтрів обробки УзД-зображень. Вимірювальна та обчислювальна техніка в технологічних процесах. 2011. №2. С. 152-157.

5. Buades A., Bartomeu C., Morel J. A Non-Local Algorithm for Image Denoising. Proceedings of the 2005 IEEE Computer Society Conference on Computer Vision and Pattern Recognition (CVPR'05), 2005. Vol. 2. P. 60-65. https://doi.org/10.1109/CVPR.2005.38.

6. Лукин В. В., Пономаренко Н. Н., Пискорж И. В., Поденкова С. В. Вторичная обработка многовзглядовых и последовательно получаемых изображений в радиолокационных и ультразвуковых медицинских когерентных системах. Радіоелектронні і комп ’отерні системи. 2003. № 2. С. 22-29.

7. Абрамов С. К., Кожемякин Р. А., Кривенко С. С., Пономаренко Н. Н., Лукин В. В. Эффективность фильтрации одновзглядовых РСА-изображений при пространственно коррелированных помехах. Радіоелектронні $i$ комп'ютерні системи. 2012. № 3. С. 18-25.

8. Ляшук А. Н., Вишневый С. В., Жук С. Я. Гомоморфная двухэтапная фильтрация последовательности изображений при наличии коррелированного спекл-шума. Вісник Нац. техн. ун-ту Украӥни “КПI”. Сер. Радіотехніка. Padioanaратобудування. 2017. Вип. 71. С. 52-59.

9. Родионова Н. В., Синило В. П. Способы подавления спекл-шума в радиолокационном изображении. Автометрия. 1993. № 5. С. 96-102.

10. Ляшук А. Н., Хамула С. В., Жук С. Я. Двухэтапная каузальная фильтрация однородного изображения при наличии коррелированной помехи. Вісник НТУУ “КПI”. Радіотехніка, радіоапаратобудування : збірник наукових праць. 2016. Вип. 66. С. 19-28. URL: https://ela.kpi.ua/handle/123456789/22786. 
11. Ляшук А. Н., Жук С. Я. Объединение результатов одномерной фильтрации однородного изображения и коррелированной помехи при некаузальной обработке. Вісник Національного технічного університету Украӥни “Київський політехнічний інститут”. Серія: Радіотехніка. Радіоапаратобудування. 2017. Вип. 68. C. 64-70. URL: http://nbuv.gov.ua/UJRN/VKPI_rr_2017_68_13.

12. Эфрон Б. Нетрадиционные методы многомерного статистического анализа / пер. с англ. Москва : Финансы и статистика, 1988. 263 с.

13. Vasylyshyn V. I. Adaptive variant of the surrogate data technology for enhancing the effectiveness of signal spectral analysis using eigenstructure methods. Radioelectronics and communications systems. 2015. Vol. 58. No. 3. P. 116-126. https://doi.org/10.20535/S0021347015030036.

14. Pirondini E., Vybornova A., Coscia M., Van De Ville D. A Spectral Method for Generating Surrogate Graph Signals. IEEE Signal Processing Letters. Sept. 2016.Vol. 23. No. 9. P. 1275-1278. https://doi.org/10.1109/LSP.2016.2594072.

15. Kantz H., Schreiber T. Nonlinear time series analysis. Cambridge: United Kingdom University Press, 2004. 369 p.

16. Theiler J., Eubank S., Longtin A., Galdrikian B., Farmer J. D. Testing for nonlinearity in time series: The method of surrogate data. Physica D. 1992. No. 58. P. 77-94.

17. Small M. Applied Nonlinear Time Series Analysis Applications in Physics, Physiology and Finance. Singapore: World Scientific Publishing Co. Pte. Ltd., 2005. 245 p.

18. Василишин В.І. Адаптивная коррекция предварительной обработки сигналов с использованием технологии суррогатных данных в задачах спектрального анализа. Системи обробки інформації. 2013. № 2(109). С. 15-20.

19. Kostenko P. Y., Slobodyanyuk V. V., Vasiuta K. S., Vasylyshyn V. I. Measure of filtering quality assessment of image noise using nonparametric statistic. Radioelectronics and Communications Systems. 2020. Vol. 63. No. 4. P. 201-212. https://doi.org/10.3103/S0735272720040032.

\section{References}

1. Fal'kovich, S.and Kostenko, P. (2006), "Osnovy statisticheskoy teorii radiotekhnicheskikh sistem” [Fundamentals of the statistical theory of radio engineering systems], NAU KhAI Publ., Kharkiv, 390 p.

2. Kostenko, P., Slobodyanuk, V. and Plahotenko, O. (2016), Method of image filtering using singular decomposition and the surrogate data technology, Radioelectronics and Communications Systems, No. 59, pp. $409-416$. https://doi.org/10.3103/S0735272716090041.

3. Kostenko, P., Slobodyanuk, V. and Kostenko, I. (2019), Method of image denoising in generalized phase space with improved indicator of spatial resolution, Radioelectronics and Communications Systems, No. 62, pp. $368-375$. https://doi.org/10.3103/S0735272719070045.

4. Bilynskyi, Y., Melnychuk, A. and Pavliuk, O. (2011), "Matematychna model spekl-shumu ta analiz filtriv obrobky UZD-zobrazhen" [Speckle noise mathematical model and analysis of ultrasound image processing filters], Meassuring and computing devices in technological processes, No. 2, pp. 152-157.

5. Buades, A., Coll, B., and Morel, J. ( 2005), A non-local algorithm for image denoising, 2005 IEEE Computer Society Conference on Computer Vision and Pattern Recognition (CVPR'05), No. 2, pp. 60-65.

6. Lukin, V., Ponomarenko, N., Piskorzh, I. and Podenkova, S. (2003), "Vtorichnaya obrabotka mnogovzglyadovyih i posledovatelno poluchaemyih izobrazheniy $\mathrm{v}$ radiolokatsionnyih i ultrazvukovyih meditsinskih kogerentnyih sistemah" [Secondary processing of multi-view and sequentially obtained images in radar and ultrasound medical coherent systems], Radioelectronic and computer systems, No. 2, pp. 22-29.

7. Abramov, S., Kozhemyakin, R., Krivenko, S., Ponomarenko, V. and Lukin, V. (2012), "Effektivnost filtracii odnovzglyadovyh SAR-izobrazhenij pri prostranstvenno korrelirovannyh pomehah"[ Efficiency of filtering single-view SAR images with spatially correlated noise], Radioelectronic and computer systems, No. 3, pp. 18-25.

8. Lyashuk, A., Vishnevyiy, S. and Zhuk, S. (2017), "Gomomorfnaya dvuhetapnaya filtratsiya posledovatelnosti izobrazheniy pri nalichii korrelirovannogo spekl-shuma" [Homomorphic two-stage filtering of an image sequence in the presence of correlated speckle noise], Bulletin of National Technical University of Ukraine. Series Radiotechnique, radioapparatus building, No. 71, pp. 52-59.

9. Rodionova, N. and Sinilo, V. (1993), "Sposobyi podavleniya spekl-shuma v radiolokatsionnom izobrazhenii” [Methods for suppressing speckle noise in a radar image], Autometry, No. 5, pp. 96-102.

10. Lyashuk, A., Xamula, S. and Zhuk, S. (2016), "Dvuhetapnaya kauzalnaya filtratsiya odnorodnogo izobrazheniya pri nalichii korrelirovannoy pomehi" [Two-stage causal filtering of a homogeneous image in the presence of correlated noise], Bulletin of National Technical University of Ukraine. Series Radiotechnique, radioapparatus building, No. 66, pp. 19-28, available at: https://ela.kpi.ua/handle/123456789/22786.

11. Lyashuk, A. and Zhuk, S. (2017), "Ob'edinenie rezultatov odnomernoy filtratsii odnorodnogo izobrazheniya i korrelirovannoy pomehi pri nekauzalnoy obrabotke" [Combining the results of one-dimensional filtering of a homogeneous image and correlated noise with non-causal processing], Bulletin of National Technical University of Ukraine. Series Radiotechnique, radioapparatus building, No.68, pp.64-70, available at: nbuv.gov.ua/UJRN/VKPI_rr_2017_68_13.

12. Efron, B. (1988), "Netraditsionnyie metodyi mnogokratnogo statisticheskogo analiza" [Non-traditional methods of multiple statistical analysis], Finance and Statistics, Moscow, $263 \mathrm{p}$

13. Vasylyshyn, V. (2015), Adaptive variant of the surrogate data technology for enhancing the effectiveness of signal spectral analysis using eigenstructure methods, Radioelectronics and Communications Systems, No. 58, pp. 116-126. https://doi.org/10.3103/S0735272715030036.

14. Pirondini, E., Vybornova, A., Coscia, M. and Van De Ville, D. (2016), A spectral method for generating surrogate graph signals, IEEE Signal Process. Letters, No. (23)9, pp. 1275-1278. https://doi.org/10.1109/LSP.2016.2594072.

15. Kantz, H., Schreiber, T (2004), Nonlinear time series analysis, United Kingdom University Press, Cambridge, 369 p. 
16. Theiler, J., Eubank, S., Longtin, A., Galdrikian, B. and Farmer, J.D. (1992), Testing for nonlinearity in time series: the method of surrogate data, Physica D: Nonlinear Phenomena, No. 58, pp.77-94.

17. Small, M. (2005), Applied Nonlinear Time Series Analysis: Applications in Physics, Physiology and Finance, World Scientific Publishing, Singapore, 245 p.

18. Vasylyshyn, V. (2013), “Adaptyvnaja korrekcyja predvaryteljnoj obrabotky syghnalov s yspoljzovanyem tekhnologhyy surroghatnykh dannykh $\mathrm{v}$ zadachakh spektraljnogho analyza" [Adaptive correction of signal preprocessing using surrogate data technology in problems of spectral analysis], Information Processing Systems, No. 2(109), pp. 15-20.

19. Kostenko, P.Y., Slobodyanyuk, V.V., Vasiuta, K.S. and Vasylyshyn, V.I. (2020), Measure of filtering quality assessment of image noise using nonparametric statistic, Radioelectronics and Communications Systems, No. 63(4), pp. 201-212. https://doi.org/10.3103/S0735272720040032.

Надійшла до редколегії 17.11.2021

Схвалена до друку 14.12.2021

Відомості про авторів:

\section{Костенко Павло Юрійович}

доктор технічних наук професор

професор кафедри Харківського національного

університету Повітряних Сил ім. І. Кожедуба,

Харків, Україна

https://orcid.org/0000-0002-3382-0684

Слободянюк Валерій Валерійович

кандидат технічних наук

старший викладач Харківського національного університету Повітряних Сил ім. І. Кожедуба,

Харків, Україна

https://orcid.org/0000-0002-8291-8194

\section{Карлов Дмитро Володимирович}

доктор технічних наук старший науковий співробітник начальник кафедри Харківського національного університету Повітряних Сил ім. І. Кожедуба, Харків, Україна

https://orcid.org/0000-0002-3786-2160

\section{Ветлугін Євген Володимирович}

кандидат технічних наук

науковий співробітник

Радіоастрономічного інституту

Національної академії наук України,

Харків, Україна

https://orcid.org/0000-0003-2721-5717

\section{Лєбєдсв Віталій Олександрович}

кандидат технічних наук

провідний науковий співробітник

Харківського національного університету

Повітряних Сил ім. І. Кожедуба,

Харків, Україна

https://orcid.org/0000-0002-6552-4599
Information about the authors:

\section{Pavel Kostenko}

Doctor of Engineering Science Professor

Professor of Department of Ivan Kozhedub Kharkiv

National Air Force University,

Kharkiv, Ukraine

https://orcid.org/0000-0002-3382-0684

\section{Valeriy Slobodyanuk}

$\mathrm{PhD}$ in Engineering

Senior Lecturer of Ivan Kozhedub Kharkiv

National Air Force University,

Kharkiv, Ukraine

https://orcid.org/0000-0002-8291-8194

\section{Dmytro Karlov}

Doctor of Engineering Science Senior Researcher

Head of Department of Ivan Kozhedub Kharkiv

National Air Force University,

Kharkiv, Ukraine

https://orcid.org/0000-0002-3786-2160

\section{Yevhen Vetluhin}

$\mathrm{PhD}$ in Engineering

Researcher

of the Radio Astronomical Institute

of the National Academy of Sciences of Ukraine,

Kharkiv, Ukraine

https://orcid.org/0000-0003-2721-5717

Vitaly Liebiediev

$\mathrm{PhD}$ in Engineering

Leading Researcher

of Ivan Kozhedub Kharkiv National

Air Force University,

Kharkiv, Ukraine

https://orcid.org/0000-0002-6552-4599

\section{МЕТОД ФИЛЬТРАЦИИ МУЛЬТИПЛИКАТИВНОГО ШУМА НА ИЗОБРАЖЕНИЯХ С ИСПОЛЬЗОВАНИЕМ ТЕХНОЛОГИИ СУРОГАТНЫХ ДАННЫХ}

П.Ю. Костенко, В.В. Слободянюк, Д.В. Карлов, Е.В. Ветлугин, В.А. Лебедев

В статье рассматривается метод фильтрации мультипликативного шума на иифровом изображении, основанный на представлении гомоморфного образа изображения в векторно-матричном фазовом пространстве и использовании нетрадичионных методов многомерного статистического анализа, а именно технологии суррогатных данных, позволяющей из единого изображения, искаженного мультипликативным шумом, формировать псевдоансамбль изображений с последующим их усреднением. Проведено имитачионное моделирование предложенного метода фильтраиии шума. Проведен визуальный сравнительный анализ пространственной и радиометрической разрешающей способности предложенного и известных методов фильтрации шума и их численных мер качества. Показано, что предложенный метод демонстрирует лучшую пространственную и радиометрическую разрешающую способность по сравнению с наиболее распространенными методами фильтрации шума.

Ключевые слова: иифровое изображение, технология суррогатных данных, мультипликативный шум, пространственная разрешающая способность, радиометрическая разрешающая способность. 


\section{METHOD OF FILTERING MULTIPLICATIVE NOISE ON A DIGITAL IMAGE USING SURROGATE DATA TECHNOLOGY}

P. Kostenko, V. Slobodyanuk, D. Karlov, Y. Vetluhin, V. Liebiediev

A fundamental problem in the field of image processing is effectively suppressing noise while retaining important image details that are necessary for later image recognition and interpretation. The complexity of solving this problem depends significantly on the type of noise. Usually, models of additive and multiplicative noise are used to describe random influences. As a statistical model of additive distortions in the processing of signals and images, they are usually represented by continuous and impulse random influence. Multiplicative noises, affecting the image, distort and at the same time increase the spatial changes in the intensity of the image (the dynamic range of their brightness). The main goal of any method for filtering images distorted by noise is to reduce its level and at the same time preserve its details and features. This problem in the case of distortions of a digital image by additive noise can be solved using known approaches. Another way to solve the problem of filtering images in the case of multiplicative noise. In most cases, statistical models of multiplicative noise are used in the form of non-Gaussian distributions, for example, Rayleigh distributions, lognormal, exponential, etc. This model describes well diffuse noise in coherent optical and radar imaging systems. The article discusses the method of filtering multiplicative noise on a digital image, based on the representation of a homomorphic image in the vector-matrix phase space and the use of unconventional methods of multivariate statistical analysis, in particular, surrogate data technology, which allows from a single image distorted by multiplicative noise. shown with their subsequent averaging Simulation modeling of the proposed noise filtering method has been performed. A visual comparative analysis of the spatial and radiometric resolution of the proposed and known methods of noise filtering and their numerous quality measures is carried out. It is shown that the proposed method demonstrates a wider spatial and radiometric resolution in comparison with the most common methods of noise filtering.

Keywords: digital image, surrogate data technology, multiplicative noise, spatial resolution, radiometric resolution. 